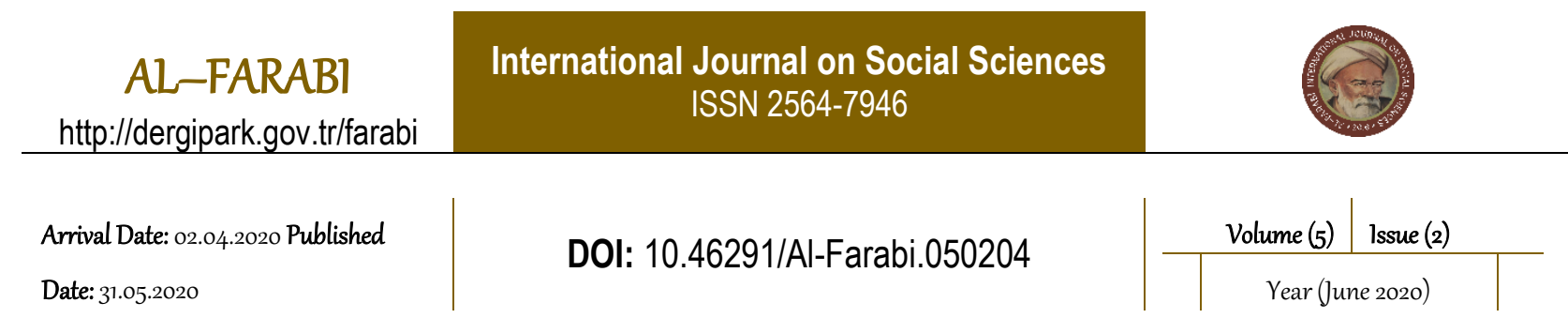

\title{
Lise Öğretmenlerinin Duygusal Emek Davranışları ile İşle Bütünleşmeleri Arasındaki İlişki ${ }^{1}$
}

\author{
The Relationship Between High School Teachers' Emotional Labor Behaviors and \\ Work Engagements
}

\section{Eda ÇARIKCI ${ }^{2}$}

\begin{abstract}
ÖZET
$\mathrm{Bu}$ araştırmanın amacı, lise öğretmenlerinin duygusal emek davranışları ile işle bütünleşmeleri arasındaki ilişkiyi saptamaktır. İlişkisel tarama modelindeki bu araştırmaya uygun örnekleme yöntemi ile belirlenen 251 öğretmen katılmıştır. Araştırmada, veri toplama araçları olarak "Duygusal Emek Ölçeği”" ve "İşle Bütünleşme Ölçeği” kullanılmıştır. Araştırma bulgularına göre, lise öğretmenlerinin duygusal emek davranışları arasında yer alan derinden rol yapma davranışlarını ve doğal duyguları çoğu zaman sergiledikleri, yüzeysel rol yapma davranışlarını ise nadiren sergiledikleri görülmüştür. İşle bütünleşmeye yönelik ise en fazla fiziksel ve bilişsel bütünleşme davranışları olmak üzere yüksek düzeyde duygusal bütünleşme davranışları gösterdikleri görülmüştür. Yüzeysel rol yapma boyutu ile duygusal bütünleşme boyutu arasında negatif yönlü anlamlı bir ilişki yer alırken, doğal duygular boyutu ile duygusal bütünleşme, fiziksel bütünleşme ve bilişsel bütünleşme boyutları arasında pozitif yönlü anlamlı ilişkiler olduğu görülmüştür. Bu ilişki en çok da duygusal bütünleşme ve doğal duygular boyutları arasındadır. Duygusal emek davranışlarının, işle bütünleşme davranışlarından fiziksel bütünleşme hariç duygusal ve bilişsel bütünleşme davranışlarının anlamlı bir yordayıcısı olduğu görülmüştür.
\end{abstract}

Anahtar Kelimeler: Duygusal emek, işle bütünleşme, lise ögrretmenleri

\begin{abstract}
The aim of this study is to determine the relationship between emotional labor behaviors and work engagement of high school teachers. The study is in the relational screening model. 251 teachers determined by the appropriate sampling method participated in this study. In the study, "Emotional Labor Scale" and "Business Engagement Scale" were used as data collection tools. According to the findings of the research, it was observed that high school teachers often show deep role-playing behaviors and natural emotions, which are among the emotional labor behaviors, while they rarely show superficial role-playing behaviors. It has been observed that teachers show a high level of emotional engagement behaviors, mostly physical and cognitive engagement behaviors for work engagement. While there was a negative meaningful relationship between the superficial role-playing dimension and the emotional engagement dimension, there was a positive meaningful relationship between the natural emotions dimension and the emotional engagement, physical engagement and cognitive engagement dimensions. This relationship is mostly among the dimensions of emotional engagement and natural emotions. Emotional labor behaviors were seen to be a significant predictor of emotional and cognitive engagement behaviors other than physical engagement behaviors.
\end{abstract}

Key Words: Emotional labor, work engagement, high school teachers

\section{GíRIŞ}

Çalışanların iş yaşamından duydukları tatmin, bir dizi ilişkiler ağıyla şekillenmektedir. Gelecek nesillerin yetiştirilmesi sorumluluğunu taşıyan öğretmenlerin görevlerini severek ve isteyerek yerine

\footnotetext{
${ }^{1} \mathrm{Bu}$ çalışma 15-17 Mart 2019 tarihleri arasında Malatya'da düzenlenen Battalgazi II. Uluslararası Multidisipliner Çalışmalar Kongresi'nde sözlü bildiri olarak sunulmuştur.

${ }^{2}$ Eğitim Uzmanı, Sahil Güvenlik Komutanlığı, Ankara, crkceda@ gmail.com, https://orcid.org/0000-0002-5735-2758
} 
getirmeleri temelde işlerinden duydukları tatmin düzeyiyle ilgilidir. İş yaşamında stres iş tatminini de olumsuz etkilemektedir (Aydın, 2008: 97). En stresli işlerden biri olan öğretmenlik mesleğinin aşırı iş yükü, uygunsuz öğrenci davranışları, meslek içinde sürekli değişim, yetersiz kaynaklar, meslektaşlarla ve velilerle zayıf ilişkilerle birlikte bu etkileşimlerden dolayı oluşan farklı duyguların neticesinde uygun davranışların sergilenmesini gerektiren zorlu bir meslek olduğunu söylemek mümkündür (Akman ve İmamoğlu-Akman, 2017). Moorman'a (1993) göre uzun süreli ve çok çeşitli duygu sergilemenin beklenildiği durumlar daha çok çaba gerektirmekte, gerçekte hissedilen duygular ve sergilenen duygular arasında bir uyumsuzluk olması halinde de bu durum bireyde tükenmişlik ve çeşitli alanlarda tatminsizlik hissi gibi birtakım olumsuz sonuçlara yol açabilmektedir (Gürel ve Bozkurt, 2016).

Meslek hayatındaki zorlayıcı faktörler ve beraberindeki stresin öğretmenlerin işlerinden duydukları tatmini de etkilediği söylenebilir. Öğretmenlik mesleğinde işten duyulan tatminin azalması birçok olumsuzluğu meydana getirmekte ve mesleki tükenmişliğin yaşanmasına da yol açmaktadır (Dinham ve Scott, 1996). Tükenmişlik, insanlarla yüz yüze ilişki gerektiren mesleklerde daha fazla görülmektedir (Maslach ve Jackson). Öğretmenlik de bu mesleklerden biridir. Öğretmenlerin çalışırken kendilerini ne kadar zinde, yoğunlaşmış ve adanmış hissettiklerini yansıtan güdüsel bir kavram olarak ele alınan işle bütünleşme, tükenmişliğin karşıtı olarak görülmektedir (Kavgacı, 2014: 10). İşle bütünleşme yaşayan öğretmenlerin ise tükenmişlik hissine kapılma ihtimallerinin daha düşük olduğu gözlenmiştir (Bermejo, Hernández-Franco ve Prieto-Ursúa, 2013). Tükenmişlik, çalışanların kişisel ve sosyal uyumlarını zedelerken işlerine karşı olan tutumlarını etkilemekte, işle bütünleşmelerini de azaltmaktadır (Gündüz, Çapri, Gökçakan, 2013: 30). Kahn (1990), işle bütünleşmeyi, örgüt üyelerinin iş rollerine bürünmeleri olarak açıklamaktadır.

İlgili literatür incelendiğinde öğretmenlerin işle bütünleşmeleri üzerine yapılan bazı çalışmalarda öğretmenlerin işle bütünleşmesinin özerklik ve yönetici desteği (Bakker \& Bal, 2010; Hakanen, Bakker \& Schaufeli, 2006; Konermann, 2011; Simbula, Guglielmi \& Schaufeli, 2011), meslektaş desteği (Simbula vd., 2011; Kirkpatrick, 2009), öz yeterlik (Basikin, 2008; Hoigaard, Giske ve Sundsli, 2012; Simbula vd., 2011; Kavgacı ve Çalık, 2017), eğitime inanma düzeyi (Gün, 2017), öğrenci davranış problemleri (Hakanen vd., 2006), örgütsel bağlılık (Hakanen vd., 2006), örgütsel vatandaşlık (Konermann, 2011), örgütsel adalet (Akşit-Aşık, 2016; Akdeniz, 2018), örgüt iklimi (Arı, 2011; İnanır, 2020), öğretmen liderliği (İnanır, 2020), lider-üye etkileşimi (Kavgacı ve Çalık, 2017), iş özelliklerine yönelik alg1 (Demirbaş, 2008), iş yaşam kalitesi algısı (Lethinen, 2013; Akamn ve İmamoğlu-Akman, 2017), değişime direnç (Çelik, 2019), yöneticiye duyulan güven (Chughtai ve Buckley, 2009), iş yaşamında yalnızlık (Sezen, 2014), işten ayrılma niyeti (Öncel, 2007; Høigaard vd., 2012) ve bazı demografik değişkenlerle (Basikin, 2007; Kong, 2009; Simbula vd., 2011) ilişkili olduğu ortaya konmuştur. Türkiye'de işle bütünleşme üzerine yapılan çalışmaların büyük çoğunluğunun işletme alanında gerçekleştirildiği görülmektedir (Dalay, 2007; Güneşer, 2007; Bal, 2008; Öner, 2008; Ar1, 2011; Turgut, 2011; Lehtinen, 2013).

Yapılan araştırmalar ve tanımların ortak noktası ise işle bütünleşme algısının yüksek olmasının birey ve örgüt için olumlu sonuçlar doğuracağıdır (Demirbaş, 2008). Araştırmalara göre işle bütünleşmeyi etkileyen faktörler duruma göre şekillenen örgütsel (örgütsel adalet, örgüt iklimi vb.) ve bireysel faktörler (öz-yeterlik, iş doyumu vb.) olarak ikiye ayrılmaktadır (Akman ve Akman, 2017). Bireysel faktörler arasında örgütün amaçları doğrultusunda gerekli görülen ve yapılan işin bir parçası olarak belirli bir duygusal ifadenin yansıtılmasını açıklayan duygusal emek kavramını da (Miller, Considine ve Garner, 2007) ele almak mümkündür. Grandey'e (2000) göre, duygusal emek hizmet veren örgütler için gereklidir çünkü bu örgütlerde çalışanlar, kurallar ve normlar gereği uygun duygusal emek davranışı sergilemek durumundadırlar. Bu kapsamda duygusal emek, öğretmenlik gibi hizmet tabanlı mesleklerde çalışanlarda daha sık görülmektedir (Karakaş, Tösten, Kansu ve Aydın, 2016). Bir öğretmenin kendisini işine adaması, enerjisini işine harcaması ve işine yönelik olumlu duygular taşıması, motivasyonla birlikte bir emeğin göstergesi olarak ele alınabilir. Doğal veya yüzeysel de olsa sergilenen duygusal emek davranışlarının, yapılan işe duyulan bağlılıkla ilişkili olabileceği düşünülmektedir. $\mathrm{Bu}$ araştırmada lise öğretmenlerinin duygusal emek davranışları ile işle 
bütünleşmeleri arasında nasıl bir ilişki olduğunu ve duygusal emek davranışının işle bütünleşmeyi nasıl etkilediğini incelemek amaçlanmıştır. Ayrıca lise öğretmenleriyle gerçekleştirilen çalışmalar sınırlı sayıda olduğu için bu çalışmanın, alandaki söz konusu boşluğu doldurmaya yönelik önemli katkı sağlayacağı düşünülmektedir.

\section{Duygusal Emek}

İş hayatında, yapılan işe özgü olarak bireyin sahip olması gereken bazı bilişsel ve duyuşsal gereklilikler söz konusudur. Çalışma hayatının bir girdisi olarak duyuşsal gereklilikleri ele alan ilk çalışma, 1979 yılında Hochschild tarafından yapılmıştır (Türkay, Ünal \& Taşan, 2011). Hochschild (1979) duyguları, kişinin yönetsel deneyimleri doğrultusunda kendi çevresi ve örgüt yapısı bütününde yönetilebilir bir olgu olarak ele almaktadır. Duygusal emek, çalışanların işlerini yaparken göstermeleri gereken isimsiz görevleri temsilen (Mastracci, Newman \& Guy, 2006), hitap edilen kesimle yakın ilişkiler kurulmasını gerektiren işlerde işin gereklerini ortaya koyabilmek için harcamak zorunda kaldıkları emek biçimidir (Topateş \& Kalfa, 2009: 425). Duygusal emek kavramı, duyguların ifadesinin nasıl uygun olup olmadığının değerlendirilmesini ve duyguların yönetimini içermektedir (Brown \& Brooks, 2002). Genel olarak duygusal emeği, fiziksel ve mental çalışmanın yanında, karşı tarafa uygun bir yüz ifadesi yansıtacak biçimde hislerini kontrol altına alma olarak açıklamak mümkündür (Hochschild, 2003: 7). Başka bir ifadeyle duygusal emek, çalışanların hissettikleri duyguları, örgüt tarafından gösterilmesi istenen duygular doğrultusunda düzenlemeleri ve sergilemeleridir (Pala \& Sürgevil, 2016).

Duygusal emek kavramını Hochschild (2003: 35), yüzeysel ve derin davranışla açıklarken; Ashforth ve Humprey (1993) ise, çalışanların gerçekten içlerinden gelerek hissedeceği davranışların da olabileceğini düşünerek, Hochschild'in yaklaşımına bir üçüncü bileşen olarak doğal duyguları eklemiş ve duygusal emeği; yüzeysel davranış, derin davranış ve doğal duygular olarak üç bileşenle ele almıştır ve duygusal emek kavramına ilişkin en yaygın kullanılan yaklaşım da bu olmuştur. $\mathrm{Bu}$ yaklaşıma göre yüzeysel rol yapma, bireylerin, gerçek hislerini değiştirmedikleri halde, duygularını gizleyerek ve duygu gösterimlerini kontrol ederek örgütün beklentilere uyumlu hale getirdikleri davranış biçimidir (Grandey, 2003; Oral \& Köse, 2011). Derinden rol yapma davranışı ise çalışanın, örgüt tarafından belirlenen kurallara uymak için içsel duygularını ve düşüncelerini kontrol ederek, kendisinden istenen rolü bir aktör ya da aktrist gibi oynamaya odaklanmasını ifade etmektedir (Brotheridge \& Grandey, 2002). Duygusal emeğin bir diğer bileşeni de samimi davranış olarak da ifade edilen doğal duygulardır (Asforth \& Humphrey, 1993; Diefendorff vd., 2005). Ashforth ve Humphrey (1993), derin ve yüzeysel davranışın gösterilebilmesi için çalışanın çaba harcaması gerekirken, doğal duyguların kendiliğinden oluşabileceğini ve gerçekten hissettiği duygularla örtüşebileceğini ifade etmiştir. Bu bakımdan duygusal emeğin kurumun kontrolünde yönetilmesi gerekmektedir. Bu olmadığı takdirde kuruma karşı gelişecek duygusal değerlendirmeler olumsuz algıları pekiştirebilecektir. Duygusal unsur daha çok kaynak ile alıcı arasında gelişen ve tanımlanamayan; ancak varlığı kabul edilen olgulara karşılık gelmektedir (Aydın ve Yayla, 2018: 74).

\section{İşle Bütünleşme}

Çalışma hayatında bireyin kendisini işin bir parçası olarak görmesi, örgüt içinde kendisinden beklenen rol davranışı ile bireyin gerçekleştirmek için beklenti duyduğu rol davranışının uyuşmasıyla mümkün olabilmektedir. Örgüt içinde iş rolü, örgütün bireyden beklentisini ve yerine getirmesini istediği davranışları iletmede bir araç olmaktadır ve bu noktada bireyin örgütün taleplerini yerine getirmesinin ön koşulu ise rolü ile önemli ölçüde bütünleşmesidir (Katz \& Kahn, 1997: 194).

İşle bütünleşme algısını kavramsal olarak ifade eden çalışmalar Goffman'ın (1959) rolü benimseme yaklaşımıyla başlamış; ardından rolü benimsemeye etki eden faktörleri tespit etmek üzere Kahn'ın (1990) çalışmaları ile devam etmiştir. Sonrasında ise bu kavramın, bütünleşmeyi tükenmişliğin karşıtı 
olarak gören Maslach ve Leiter (1997) ve bu görüşe karşı çıkan Schaufeli vd. (2002) tarafından daha da geliştirildiği söylenebilmektedir.

İşle bütünleşme kavramını tanımlamaya yönelik olarak Goffman (1959), bireyin içsel enerjisini kendisinden beklenen role aktarması ile rolünü benimseyeceğini ve bunun da bir dikkat ve çabanın ürünü olduğunu ifade etmiştir. Sonraki çalışmalarda, bireyin rolünü benimsemesine etki eden faktörler incelenmiş ve bireylerin iş rollerini gerçekleştirme davranışlarında farklılıklar olduğu tespit edilmiştir. Bir kısım çalışanın, üstlendikleri iş rollerini fazla çaba harcamadan basit düzeyde gerçekleştirirken, bir kısım çalışanın da kendilerini iş rollerine adayarak üst düzey çaba harcadıkları ve bunu gerçekleştirirken rolleriyle bütünleşme yaşadıkları gözlemlenmiştir (Kahn, 1990). Buradan hareketle işle bütünleşmenin, fiziksel, duygusal ve bilişsel düzeyde gerçekleşen bir işe adanış olduğu ileri sürülmüştür (Rich, 2006: 13).

Fiziksel bütünleşme, bireyin iş rollerini gerçekleştirirken sahip olduğu enerji ve hareketliliği; duygusal bütünleşme, bireyin işini sevmesini, işine, çalışma ortamına, çalışma grubuna ve yöneticilerine karşı beslediği olumlu ve olumsuz duyguları ve bu duygularla yansıttığı tutumu; bilişsel bütünleşme ise bireyin, kendisine verilen iș rollerinin bilinciyle, işine, yöneticilerine ve çalıştığı örgüte inanmasını ifade etmektedir (Schmitt, 2012; Rich, Lepin \& Crawford, 2010: 621; Bakker \& Oerlemans, 2011: 178). Kahn (1990), işle bütünleşmenin devamlılığını sağlayacak unsurları incelemiş ve bunun sonucunda, bireyin iş rollerini gerçekleştirirken harcadığ çabanın karşılığında yaptığı işin değerini yansıtan 'psikolojik anlamlılık'; iş arkadaşları ile yöneticileri tarafindan sağlanan destek ve verilen önem sonucu bireyin hissettiği duyguyu ifade eden 'psikolojik güvenlik' ve bireyin üstlendiği rol ile kişisel değerlerinin uyuşmasını ifade eden 'uygunluk' kavramı olarak adlandırdığı motivasyon temelli üç psikolojik unsurdan söz etmiştir (Albrecht, 2006: 22; Babcock-Roberson \& Strickland, 2010: 315; Collins, 2009: 17).

İşle bütünleşme kavramını tanımlamaya yönelik bir başka kuramsal yaklaşım Maslach ve Leiter (1997)'e aittir. Leiter ve Maslach (1997), işle ilgili olumsuz zihinsel ve duygusal bir süreç olarak ele alınan tükenmişliğin, işle bütünleşmenin tam karşıtı olduğunu ileri sürdükleri Tükenmişlik Antitezi Yaklaşımı (Schaufeli, 2014:15) ile tükenmişlik ve işle bütünleşme kavramları arasındaki negatif yönlü ilişkiden hareket ederek, bireylerin işle bütünleşme düzeyini saptamak için tükenmişlik düzeyinin ölçülmesinin yeterli olduğunu öne sürmüşlerdir (Bal, 2009: 546). Bu yaklaşıma karşı çıkan Schaufeli (2014), tükenmişlik ve işle bütünleşmenin kavramsal olarak birbiri ile ilişkili olduğunu fakat iki kavramın aynı ölçek ile ölçülmesinin doğru sonuçlar vermeyeceğini ileri sürmüştür (Rich, 2006: 4).

İşle bütünleşme kavramı en genel ifadeyle, kişinin işine yönelik olarak yüksek bir motivasyon ve enerjiyle dolu olması, psikolojik olarak olumlu duygular taşıması ve işine bütünüyle bağlanması anlamını taşımaktadır (Hallberg \& Schaufeli, 2006). Bireyin işle ilgili pozitif psikoloji yönünden iyi olma veya kendini gerçekleştirme durumunu ifade eden işle bütünleşme, kişisel enerjinin işe yansıtılması ve işin önemli görülmesini açıklamaktadır (Bakker \& Leiter, 2010: 182).

\section{Araştırmanın Amacı}

$\mathrm{Bu}$ araştırmanın amacı lise öğretmenlerinin duygusal emek davranışları ile işle bütünleşmeleri arasındaki ilişkiyi -incelemektir. Bu amaçla aşağıdaki alt problemlere cevap aranmıştır:

- Lise öğretmenlerinin duygusal emek ve işle bütünleşme düzeyleri nedir?

- Lise öğretmenlerinin duygusal emek düzeyi ile işle bütünleşme düzeyi arasında anlamlı bir ilişki var mıdır?

- Lise öğretmenlerinin duygusal emek gösterimi, işle bütünleşmelerinin anlamlı bir yordayıcısı mıdır?

\section{Kapsam ve Sinırlılıklar}


Bu araştırma Türkiye genelinde çeşitli resmi ve özel liselerde görev yapan öğretmenlerin görüşleriyle sınırlıdır. "Duygusal Emek Ölçeği” ve "İşle Bütünleşme Ölçeği” nde yer alan maddeler araştırmanın kapsamını oluşturmaktadır.

Ayrıca araştırmada, çalışma grubunun yeterli temsil gücüne sahip olduğu, uygulanan anket formuna doğru ve yansız cevap verildiği; belirlenen araştırma yönteminin, lise öğretmenlerinin duygusal emek davranışları ile işle bütünleşmeleri arasındaki ilişkiyi ortaya çıkarabileceği temel varsayımlarından hareket edilmiştir.

\section{YÖNTEM}

\section{Araştırmanın Modeli}

İlişkisel tarama modelinin kullanıldığı bu araştırmada, lise öğretmenlerinin duygusal emek davranışları ile işle bütünleşme davranışlarının düzeyleri arasındaki ilişkiler incelenmiştir. İlişkisel tarama, iki veya daha çok değişken arasındaki birlikte değişimin varlığını ve derecesini belirlemeyi amaçlayan bir araştırma modelidir (Karasar, 2010). Araştırmada öğretmenlerin duygusal emek davranışları bağımsız değişken; işle bütünleşme davranışları ise bağımlı değişken olarak belirlenmiştir.

\section{Evren ve Örneklem}

Araştırmada uygun örnekleme yöntemi kullanılmıştır. Uygun örnekleme yöntemi, araştırmacıya yakın ve erişilmesi kolay olan bir örneklem seçilmesi yönüyle araştırmaya hız ve pratiklik kazandırmaktadır (Yıldırım ve Şimşek, 2011). Araştırmanın çalışma grubunu, farklı illerdeki çeşitli kamu ve özel ortaöğretim kurumlarında görev yapmakta olan 251 lise öğretmeni oluşturmaktadır. Araştırmaya katılan öğretmenlerin cinsiyet, medeni durum, yaş, branş, kıdem ve eğitim durumuna ilişkin betimleyici istatistikler tablo 1'de verilmiştir:

Tablo 1: Araştırmaya Katılan Öğretmenlerin Cinsiyet, Medeni Durum, Yaş, Branş, Kıdem ve Eğitim Durumuna İlişkin Dağılım

\begin{tabular}{|c|c|c|c|}
\hline Değişken & Kategori & $\mathrm{N}$ & $\%$ \\
\hline \multirow{3}{*}{ Cinsiyet } & Kadın & 157 & 62,5 \\
\hline & Erkek & 94 & 37,5 \\
\hline & Toplam & 251 & 100 \\
\hline \multirow{4}{*}{ Medeni Durum } & Evli & 178 & 70,9 \\
\hline & Bekâr & 66 & 26,3 \\
\hline & Dul/Boşanmış & 7 & 2,8 \\
\hline & Toplam & 251 & 100 \\
\hline \multirow{5}{*}{ Yaş } & $22-31$ yaş & 70 & 27,9 \\
\hline & $32-41$ yaş & 78 & 31,1 \\
\hline & 42-51 yaş & 79 & 31,5 \\
\hline & 52 yaş ve üzeri & 24 & 9,6 \\
\hline & Toplam & 251 & 100 \\
\hline \multirow{5}{*}{ Branş } & Sözel Branşlar & 122 & 48,6 \\
\hline & Sayısal Branșlar & 96 & 38,2 \\
\hline & Beden E./Güzel S. & 18 & 7,2 \\
\hline & Rehberlik & 15 & 6,0 \\
\hline & Toplam & 251 & 100 \\
\hline \multirow{5}{*}{ Kıdem } & $1-10 \mathrm{y} 11$ & 117 & 46,6 \\
\hline & $11-20 \mathrm{y} 1 \mathrm{l}$ & 70 & 27,9 \\
\hline & $21-30$ y1l & 50 & 19,9 \\
\hline & 31 ve üzeri & 14 & 5,6 \\
\hline & Toplam & 251 & 100 \\
\hline \multirow{2}{*}{ Eğitim Durumu } & Lisans & 194 & 77,3 \\
\hline & Yüksek Lisans & 55 & 21,9 \\
\hline
\end{tabular}


Tablo 1'de yer alan betimleyici istatistikler incelendiğinde, araştırmaya katılan öğretmenlerin yaklaşık üçte ikisinin kadın, üçte ikiden fazlasının evli, üçte birinin 32-41 ve 42-51 yaş aralıklarında, yarısına yakınının sözel branşlarda öğretmen olduğu, yarısına yakınının 1-10 yıl kıdeme sahip olduğu ve beşte dördünün lisans mezunu olduğu görülmektedir.

\section{Veri Toplama Araçları}

Araştırmada veri toplama aracı olarak Diefendorff ve arkadaşları (2005) tarafından geliştirilen, Basım ve Begenirbaş (2012) tarafından Türkçeye uyarlanan Duygusal Emek Ölçeği ile Rich (2006) tarafından geliştirilen ve Öngöre (2013) tarafından Türkçe'ye uyarlanan İşle Bütünleşme Ölçeği kullanılmıştır.

\section{Duygusal emek ölçeği (DEÖ)}

Araştırmada öğretmenlerin duygusal emek harcama düzeylerini ölçmek amacıyla, Diefendorff ve arkadaşları (2005) tarafindan geliştirilen, Basım ve Begenirbaş (2012) tarafından Türkçeye uyarlanan Duygusal Emek Ölçeği (DEÖ) kullanılmıştır. Ölçek, 3 boyutta toplam 13 maddeden oluşmaktadır. DEÖ, "Hiçbir Zaman (1), Her zaman (5)" şeklinde beşli likert tipi dereceleme türünde hazırlanmış olup, analizler için kodlamalar SPSS 21.0 programında yapılmıştır. Ölçekte yüzeysel rol yapma 6, derinden rol yapma 4 ve doğal davranışlar ise 3 madde ile ölçülmüştür (Basım ve Begenirbaş, 2012: 82). Diefendorff ve arkadaşları (2005) tarafından ölçeğin iç tutarlılı̆̆ı, yüzeysel rol yapma boyutunda $\alpha=0,92$, derinden rol yapma boyutunda $\alpha=0,85$ ve doğal duygular boyutunda ise $\alpha=0,83$ olarak bulunmuştur. Bulguların genellenebilirliğini artırmak adına iki ayrı örneklem grubunun kullanıldığ1 çalışmada, ölçeğin iç tutarlılığı için Cronbach Alpha katsayısı hesaplanmış, kapsam geçerliği için uzman görüşünden yararlanılmış ve yapı geçerliği için ise açımlayıcı ve doğrulayıcı faktör analizi yapılmıştır (Basım ve Begenirbaş, 2012: 81-82). Ölçeğin iç tutarlılık analizi sonuçları ve açıklayıcı istatistiksel bulgular Tablo 2'de verilmiştir.

Tablo 2: Duygusal Emek Ölçeği (DEÖ)'nin İç Tutarlılık Analizi Sonuçları ve Açıklayıcı İstatistiksel Bulgular

\begin{tabular}{cccccccccccc}
\hline Alt Boyutlar & \multicolumn{1}{c}{ 1.Örneklem } & \multicolumn{1}{c}{ 2.Örneklem } & \multicolumn{2}{c}{ Fark1 } & 1.Örneklem & 2.Örneklem \\
\hline & $\mathrm{N}$ & $\overline{\mathrm{x}}$ & $\mathrm{SS}$. & $\mathrm{N}$ & $\overline{\mathrm{x}}$ & $\mathrm{SS}$ & $\mathrm{t}$ & ${ }^{*} \mathrm{p}$ & $\alpha$ & $\alpha$ \\
\hline $\begin{array}{c}\text { Yüzeysel Rol } \\
\text { Yapma }\end{array}$ & 152 & 2,37 &, 79 & 273 & 2,39 &, 87 &,- 164 &, 251 &, 838 &, 844 \\
\hline $\begin{array}{c}\text { Derinden Rol } \\
\text { Yapma }\end{array}$ & 152 & 3,43 &, 99 & 273 & 3,37 &, 98 &, 651 &, 958 &, 879 &, 863 \\
\hline $\begin{array}{c}\text { Doğal } \\
\text { Duygular }\end{array}$ & 152 & 4,19 &, 69 & 273 & 4,15 &, 74 &, 644 &, 324 &, 825 &, 860 \\
\hline
\end{tabular}

Ölçeğin geçerlik çalışmaları için birinci örnekleme ait veriler yapı geçerliğini test etmek amacıyla açımlayıcı faktör analizine tabi tutulmuş, Barlett normal dağılım test sonucunun anlamlı olduğu ( $p<0,05)$ ve KMO (Kaiser-Mayer-Olkin) değerinin ise 0,841 olduğu belirlenmiştir. Faktör analizi neticesinde Diefendorff ve arkadaşlarının (2005) ortaya koyduğu yapıyla uyumlu olarak özdeğeri 1'den büyük olan 3 faktörlü bir yap1 elde edilmiştir (Basım ve Begenirbaş, 2012: 83). İkinci örnekleme ait veriler doğrulayıcı faktör analizine tabi tutulmuş ve değişkenlerin yordama gücünün anlamlı olduğu görülmüştür (Basım ve Begenirbaş, 2012: 85).

İşle bütünleşme ölçeği (İBÖ) 
Rich (2006) tarafından Kahn'ın modeline uygun olarak geliştirilmiş ve Türkçeye uyarlaması Öngöre (2013) tarafından yapılmış olan İşle Bütünleşme Ölçeği (İBÖ), üç boyutlu bir yapıya sahiptir. İşle bütünleşmenin boyutları fiziksel (FB), duygusal (DB) ve bilişsel (BB) bütünleşmedir. İBÖ’de her bir boyutu ölçmeye yönelik 6 madde vardır ve toplam madde sayısı 18'dir. Maddeler "Kesinlikle Katılmıyorum" (1), "Katılmıyorum" (2), "Kismen Katılıyorum" (3), "Kat1lıyorum" (4), "Kesinlikle Katılıyorum" (5) şeklinde puanlanan 5'li Likert tipi bir derecelendirmeye sahiptir.

Ölçeğin Öngöre (2013) tarafından yapılan uyum iyiliği indeksi sonuçlarına göre Ki-kare değerinin, serbestlik derecesine oranı 1.51 bulunmuş olup; AGFI $=0.79$, GFI $=0.85$, NFI $=0.96, \mathrm{RFI}=0.95$, $\mathrm{CFI}=0.98, \quad \mathrm{IFI}=0.95, \quad \mathrm{RFI}=0.98, \quad \mathrm{SRMR}=0.06, \quad \mathrm{RMSEA}=0.06$ ve $\% 90$ güven aralı̆̆ında RMSEA $=0.04$ olarak bulunmuştur. Güvenirlik analizi sonucunda iç tutarlılık (Cronbach Alpha) katsayısı ölçeğin tamamı için .95, alt boyutlarından FB için .91, DB için .94 ve BB için .95 bulunmuştur. Test yarılama yoluyla elde edilen güvenilirlik katsayısı ise .97'dir (Öngöre, 2013).

Öğretmenlerin duygusal emek davranışlarını ölçmek üzere kullanılan DEÖ'de beşli likert ölçeğine uygun olarak 4.21-5.00 (her zaman), 4.20-3.41 (çoğu zaman), 3.40-2.61 (bazen), 2.60-1.81 (çok nadir), 1.80-1.00 (hiçbir zaman) puan aralıkları kullanılmıştır. İBÖ'deki işle bütünleşme düzeyi aralıkları ise 4.21-5.00 (kesinlikle kat1liyorum), 4.20-3.41 (kat1liyorum), 3.40-2.61 (k1smen katılıyorum), 2.60-1.81 (katılmıyorum, 1.80-1.00 (kesinlikle katılmıyorum) şeklindedir.

\section{Verilerin Toplanması ve Analizi}

Araştırma verilerinin toplanması e-mail, online anket ve anket formlarının elden dağıtılmasıyla gerçekleştirilmiştir. Araştırmada bağımlı değişkenler, fiziksel bütünleşme, duygusal bütünleşme ve bilişsel bütünleşme; bağımsız değişkenler ise yüzeysel rol yapma, derinden rol yapma ve doğal duygular olup, bağımlı ve bağımsız değişkenler arasındaki ilişki SPSS 21.0 paket programında regresyon analizi ile tespit edilmiştir.

Verilerin analizi, eksik ve hatalı formlar ile aykırı değerlerin çıkarılması sonucu 235 veri üzerinden gerçekleştirilmiştir. Veri setinin normallik varsayımına ilişkin bulgular tablo 3'te yer almaktadır.

Tablo 3: Normallik Testi Sonuçları

\begin{tabular}{llclccc}
\hline Değişkenler & $\mathrm{n}$ & $\bar{X}$ & $\mathrm{~S}$ & Medyan & Çarpıklık & Basıklık \\
\hline Duygusal Emek & 235 & 3.10 & .47 & 3.15 & -.260 & -.198 \\
İşle Bütünleşme & 235 & 4.22 & .49 & 4.16 & -.118 & -.816 \\
\hline
\end{tabular}

Tablo 3 incelendiğinde her iki değişkene ait çarpıklık değerlerinin normallik varsayımını sağladığı görülmüştür. Hair, Black, Babin \& Anderson (2013), -1 ila +1 aralığının dışında kalan çarpıklık değerlerinin, büyük ölçüde normal bir dağılım göstermediğini ifade etmektedir. Büyüköztürk’e (2016) göre, aritmetik ortalama, mod ve medyanın birbirine yakın olması; çarpıklık ve basıklık değerlerinin de -1 ile +1 aralığında olması durumunda normallik varsayımının sağlandığı ve parametrik testlerin kullanılabileceği söylenebilmektedir. Tablo3 incelendiğinde çarpıklık ve basıklık değerlerinin -1 ile +1 arasında olması ile aritmetik ortalama ve medyan değerlerinin yakınlığı şartları sağlanmaktadır. Dolayısıyla verilerin normal dağılım gösterdiğini söylemek mümkündür. $\mathrm{Bu}$ nedenle, toplanan veriler parametrik analiz yöntemlerinden yararlanılarak çözümlenmiştir.

Değişkenler arasındaki korelasyonlar Pearson Momentler Çarpımı Korelasyon Katsayıları hesaplanarak incelenmiştir. Duygusal emek alt boyutlarının işle bütünleşmeyi yordayıcılıkları ise Çoklu Doğrusal Regresyon analizi yapılarak tespit edilmiştir. Çoklu regresyon varsayımlarını karşılamak için öncelikle değişkenler arası çoklu bağlantılık (multicollinearity) düzeyi incelenmiştir. Field'e (2005) göre çoklu regresyon analizinde en büyük VIF değerinin 10'dan küçük; tolerans değerinin ise .20'den büyük olması gerekmektedir. Bu doğrultuda, veri setine ilişkin VIF değerlerinin 
[yüzeysel rol yapma $(1,298)$; derinden rol yapma $(1,085)$; doğal duygular $(1,344)$ ] ve tolerans değerlerinin [yüzeysel rol yapma (.77); derinden rol yapma (.92); doğal duygular (.74)] şeklinde istenen düzeyde olduğu görülmüştür.

\section{BULGULAR}

Araştırmanın bu bölümünde öncelikle lise öğretmenlerinin duygusal emek ve işle bütünleşme düzeylerine ilişkin tanımlayıcı istatistiksel bulgular ve duygusal emek düzeyi ile işle bütünleşme düzeyi arasındaki ilişkilere yönelik bulgulara yer verilmiştir.

\section{Aritmetik Ortalama ve Korelasyon Analizlerine İlişkin Bulgular}

Tablo 4: Değişkenlere İlişkin Aritmetik Ortalama ve Korelasyon Değerleri ( $\mathrm{n}=235)$

\begin{tabular}{|c|c|c|c|c|c|c|c|c|c|}
\hline Ölçek & Değişkenler & $\overline{\bar{X}}$ & $\mathrm{~S}$ & 1 & 2 & 3 & 4 & 5 & 6 \\
\hline \multirow{3}{*}{ 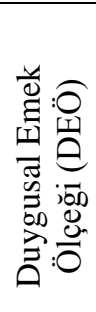 } & $\begin{array}{l}\text { 1.Yüzeysel } \\
\text { Rol Yapma }\end{array}$ & 2.32 & .84 & 1.00 & .082 & $-.445^{* *}$ & -.111 & $-.144^{*}$ & -.047 \\
\hline & $\begin{array}{l}\text { 2.Derinden } \\
\text { Rol Yapma }\end{array}$ & 3.51 & .87 & & 1.00 & $.203^{* *}$ & .377 & .071 & . 128. \\
\hline & $\begin{array}{l}\text { 3.Doğal } \\
\text { Duygular }\end{array}$ & 4.11 & .68 & & & 1.00 & $.169^{* *}$ & $.288^{* *}$ & $.175^{* *}$ \\
\hline \multirow{3}{*}{ 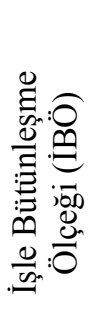 } & $\begin{array}{l}\text { 4.Fiziksel } \\
\text { Bütünleşme }\end{array}$ & 4.24 & .54 & & & & 1.00 & $.578^{* *}$ & $.662^{* *}$ \\
\hline & $\begin{array}{l}\text { 5.Duygusal } \\
\text { Bütünleşme }\end{array}$ & 4.14 & .63 & & & & & 1.00 & $.594^{* *}$ \\
\hline & $\begin{array}{l}\text { 6.Bilişssel } \\
\text { Bütünleşme }\end{array}$ & 4.28 & .55 & & & & & & 1.00 \\
\hline
\end{tabular}

$* * \mathrm{p}<.01 ; * \mathrm{p}<.05$

Tablo 4'te yer alan veriler incelendiğinde, lise öğretmenlerinin duygusal emek davranışına yönelik doğal duygular $(\bar{X}=4.11)$ ve derinden rol yapma $(\bar{X}=3.51)$ boyutlarındaki davranışları çoğu zaman sergilerken ortalamanın altında kalan yüzeysel rol yapma $(\bar{X}=2.32)$ boyutuna ilişkin davranışları çok nadir sergiledikleri görülmektedir. Başka bir ifadeyle, lise öğretmenleri duygusal emek davranışlarından en fazla doğal duyguları yansıtan davranışları sergilerken, derinden rol yapma davranışlarını çoğu zaman, yüzeysel rol yapma davranışlarını ise nadiren sergilemektedirler. Diğer yandan öğretmenlerin, işle bütünleşme davranışlarına ilişkin algı düzeylerinin fiziksel bütünleşme ( $\bar{X}=4.24)$ ve bilişsel bütünleşme $(\bar{X}=4.28)$ boyutlarında en yüksek düzeyde, duygusal bütünleşme $(\bar{X}$ $=4.14$ ) boyutunda ise yüksek düzeyde olduğu görülmektedir. Başka bir ifadeyle, lise öğretmenleri işle bütünleşme durumlarına dair, fiziksel ve bilişsel bütünleşme davranışlarını kesinlikle sergilediklerini, duygusal bütünleşme davranışlarını da daha az olmakla birlikte iyi düzeyde sergilediklerini ifade etmektedirler. Buradan hareketle lise öğretmenlerinin işle bütünleşme düzeylerinin genel olarak yüksek olduğunu söylemek mümkündür.

Yüzeysel rol yapma ile İBÖ’nün duygusal bütünleşme $(r=-.14, p<.05)$ boyutu arasında negatif yönlü anlamlı bir ilişki görülürken, fiziksel bütünleşme $(r=-.11, p>.05)$ ve bilişsel bütünleşme $(r=$ $-.04, \mathrm{p}>.05)$ boyutları arasında ilişki bulunamamıştır. Derinden rol yapma ile İBÖ'nün fiziksel $(\mathrm{r}=$ $.37, \mathrm{p}>.05)$, duygusal $(\mathrm{r}=.07, \mathrm{p}>.05)$ ve bilişsel bütünleşme $(\mathrm{r}=.12, \mathrm{p}>.05)$ boyutlarının herhangi 
biri arasında anlamlı bir ilişki bulunamamıştır. Diğer taraftan doğal duygular ile İBÖ’nün en fazla duygusal bütünleşme $(\mathrm{r}=.28, \mathrm{p}<.01)$ boyutu arasında olmak üzere, fiziksel bütünleşme $(\mathrm{r}=.16, \mathrm{p}$ $<.01)$ ve bilişsel bütünleşme $(\mathrm{r}=.17, \mathrm{p}<.01)$ boyutları arasında pozitif yönlü anlamlı ilişkiler olduğu görülmektedir.

\section{Regresyon Analizine İlişkin Bulgular}

Bu bölümde lise öğretmenlerinin işle bütünleşme davranışlarının her bir boyutunun yordanmasına ilişkin bulgulara Tablo 5'te yer verilmiştir.

Tablo 5: Regresyon Analizine İlişkin Veriler ( $\mathrm{n}=235)$

\begin{tabular}{lccccccccc}
\hline Değişkenler & \multicolumn{3}{c}{ Fiziksel Bütünleşme } & \multicolumn{2}{c}{ Duygusal Bütünleşme } & \multicolumn{3}{c}{ Bilişsel Bütünleşme } \\
\cline { 2 - 9 } & $\beta$ & $\mathrm{t}$ & $\mathrm{p}$ & $\beta$ & $\mathrm{t}$ & $\mathrm{p}$ & $\beta$ & $\mathrm{t}$ & $\mathrm{p}$ \\
\hline \multicolumn{1}{c}{ Sabit } & & 12.30 & .00 & & 8.88 & .22 & & 11.17 & .00 \\
$\begin{array}{l}\text { 1.Yüzeysel } \\
\text { Rol Yapma }\end{array}$ & -.03 & -.69 & .48 & -.01 & -.33 & .74 & .01 & .24 & .80 \\
$\begin{array}{l}\text { 2.Derinden } \\
\text { Rol Yapma }\end{array}$ & .02 & .50 & .61 & .01 & .25 & .79 & .05 & 1.38 & .16 \\
$\begin{array}{l}\text { 3.Doğal } \\
\text { Duygular }\end{array}$ & .11 & 1.85 & .06 & .25 & 3.74 & .00 & .13 & 2.19 & .02 \\
\hline
\end{tabular}

Fiziksel Bütünleşme: $\mathrm{R}=.17, \mathrm{R}^{2}=.03, \mathrm{~F}_{(3-235)}=2.48, \mathrm{p}>.05$

Duygusal Bütünleşme: $\mathrm{R}=.28, \mathrm{R}^{2}=.08, \mathrm{~F}_{(3-235)}=6.99, \mathrm{p}<.01$

Bilişsel Bütünleşme: $\mathrm{R}=.19, \mathrm{R}^{2}=.04, \mathrm{~F}_{(3-235)}=3.17, \mathrm{p}<.05$

Tablo 5 incelendiğinde, öğretmenlerin duygusal emek davranışlarına ait yüzeysel rol yapma, derinden rol yapma ve doğal duygular boyutlarının fiziksel bütünleşme ile anlamlı bir ilişkisi görülmezken $(\mathrm{R}=$ $.17, \mathrm{p}>.05)$; duygusal bütünleşme ile anlamlı bir ilişki gösterdiği görülmüştür $(\mathrm{R}=.28, \mathrm{p}<.01)$. Yüzeysel rol yapma, derinden rol yapma ve doğal duygular yordayıcı değişkenleri, öğretmenlerin duygusal bütünleşme davranışlarına ilişkin toplam varyansın \%08'ini açıklamaktadır. Duygusal bütünleşme ile yalnızca doğal duygular boyutu arasında $(\beta=.25, \mathrm{p}<.05)$ pozitif yönlü anlamlı bir ilişki söz konusudur. Duygusal bütünleşme ile diğer iki boyut olan yüzeysel rol yapma $(\beta=-.01, p>.05)$ ve derinden rol yapma $(\beta=-01, p>.05)$ davranışları arasında anlamlı bir ilişki yoktur.

Diğer yandan yüzeysel rol yapma, derinden rol yapma ve doğal duygular yordayıcı değişkenleri ile bilişsel bütünleşme arasında da anlamlı bir ilişski görülmüştür $(\mathrm{R}=.19, \mathrm{p}<.05)$. Bu yordayıcı değişkenler bilişsel bütünleşme davranışlarına ilişkin toplam varyansın \%04'ünü açıklamaktadır. Bilişsel bütünleşme ile yüzeysel rol yapma $(\beta=.01, p>.05)$ ve derinden rol yapma $(\beta=.05, p>.05)$ davranışları arasında anlamlı bir ilişki görülmezken; doğal duygular arasında $(\beta=.13, p<.05)$ pozitif yönlü anlamlı bir ilişki söz konusudur.

\section{TARTIŞMA VE SONUÇ}

$\mathrm{Bu}$ araştırmada lise öğretmenlerinin duygusal emek davranışları ile işle bütünleşmeleri arasındaki ilişkiler incelenmiştir. Araştırmanın birinci alt problemine ilişkin bulgulara göre, lise öğretmenlerinin duygusal emek davranışlarına yönelik derinden rol yapma davranışları ve doğal duyguları çoğu zaman, yüzeysel rol yapma davranışlarını ise nadiren sergiledikleri görülmektedir. Diğer yandan işle bütünleşmeye yönelik en fazla fiziksel ve bilişsel bütünleşme davranışları olmak üzere yüksek 
düzeyde duygusal bütünleşme davranışları gösterdikleri ve genel olarak işle bütünleşme düzeylerinin ortalamanın üzerinde olduğu görülmüştür. İşle bütünleşme davranışlarına yönelik araştırma bulguları Emeksiz (2015), Guglielmi, Bruni, Simbula, Fraccaroli ve Depolo (2014), Han, Yin ve Wang (2016), Kavgacı (2014), Öncel (2007), Sezen (2014) ve Akman ve İmamoğlu-Akman'ın (2017) araştırma bulgularıyla desteklenmektedir.

Araştırmanın ikinci alt problemine ilişkin bulgulara göre duygusal emek davranışlarından doğal duygular ile en fazla duygusal bütünleşme arasında olmak üzere, fiziksel bütünleşme ve bilişsel bütünleşme boyutları arasında pozitif yönlü anlamlı ilişkiler olduğu görülmektedir. Buna göre lise öğretmenlerinin doğal duygu gösterimleri arttıkça en yüksek düzeyde duygusal bütünleşmeleri olmak üzere fiziksel ve bilişsel bütünleşme düzeyleri de artmaktadır. Bu durum, öğretmenler için gerçekten hissettikleri duyguların yansıması olarak samimi davranışlar sergilemenin işle bütünleşmelerine olan olumlu yansımasını göstermektedir.

Araştırmadaki bir diğer bulgu, yüzeysel rol yapma ile duygusal bütünleşme arasında negatif yönlü anlamlı bir ilişki olduğudur. Buna göre lise öğretmenlerinin yüzeysel rol yapma davranışları azaldıkça duygusal bütünleşme düzeyleri de artmaktadır. Yüzeysel rol yapmada duyguları sahteleştirerek yani onları gerçekte hissettiği duygulardan farklılaştırarak, yansıtma söz konusudur (Hochschild, 2003; Brotheridge ve Grandey, 2002). Dolayısıyla, gerçekten hissedilmeyen duyguların duygusal bütünleşmeyi engellediği çıkarımını yapmak mümkündür. Harcanan çabanın yoğunluğu ve sergilenen davranışın türü duygusal tükenmeyi çeşitli şekillerde etkilemektedir. Yüzeysel davranışın bireylerin duygusal tükenmişlik düzeyini arttırdığını ortaya koyan çeşitli çalışmalar söz konusudur (Yürür ve Ünlü, 2011). Näring, Vlerickc ve Van de Ven'in (2012) öğretmenler ile gerçekleştirdiği bir başka çalışmada da yüzeysel rol yapma davranışının duygusal tükenmişlik ile pozitif ilişkili olduğu ve duygusal tükenmişliğin önemli bir belirleyicisi olduğu ortaya konmuştur. İşle bütünleşmenin, tükenmişliğin karşıtı olarak ele alınması yaklaşımıyla (Maslach ve Leither, 1997), yüzeysel rol yapma davranışının artmasının işle bütünleşmeyi olumsuz etkileyeceğini söylemek mümkündür.

Araştırmanın üçüncü alt problemine ilişkin bulgulara göre, duygusal emek davranışlarının işle bütünleşmeye yönelik fiziksel bütünleşme hariç duygusal ve bilişsel bütünleşme davranışlarının anlamlı bir yordayıcısı olduğu görülmüştür. Bu durum, duygusal emek davranışlarının, öğretmenlerin işle bütünleşmelerini genel olarak olumlu yönde etkilediğini ortaya koymuştur. Kahn'a (1990) göre kişinin işiyle bütünleşmesinin söz konusu olabilmesi için belirli koşulların kabul edilebilir derecede var olması gerekmektedir. Macey ve Schneider'e (2008) göre, işle bütünleşme durumunu anlayabilmek için iş koşulları ve bireysel özellikleri birlikte değerlendirmek ve aradaki uyumu incelemek gerekmektedir. Bireysel özellikler kapsamında ele alınan duygusal emek, bireyin duygularını kontrolünü ve istenildiği doğrultuda samimi veya rol yaparak yansıtmasını ifade etmekte olup, bireyin iş rollerini benimsemesini kolaylaştırması yönüyle işle bütünleşmesine olumlu etki etmektedir.

Örgütsel boyutta ele alınan iş koşullarına bakıldığında, bireyi katı ve kesin duygu sergilemeye iten kurallar, bireye işinde kendisi gibi olamayacağını ve ortaya çıkan durumlara doğal tepkiler veremeyeceğini düşündürmektedir (Diefendorf ve Grosserand, 2003). Bu durum da bireyin işteki motivasyonuna ve iş tatminine (Grandey, 2000) olumsuz yansıyabilmekte (Lin-Chu, 2002: 24); bununla beraber duygusal tükenmişliğin artmasına yol açabilmektedir (Morris ve Feldman, 1997). Birey ve örgütün karş1lıklı etkileşimindeki olumsuzluklar tükenmişliğe neden olurken, bu etkileşimdeki uyum ise işle bütünleşmeyi sağlamaktadır (Maslach ve Goldberg, 1998). İşle bütünleşmeyi örgütsel bağl1lık, iş doyumu, motivasyon ve mesleki bağl1lık ile ilişkilendiren çalışmalar (Maslach, Schaufeli ve Leiter, 2001; Saks, 2006; Hallberg ve Schaufeli, 2006; Hakanen, Bakker ve Schaufeli, 2006; Halbesleben, 2010; Bakker, Demerouti ve Sanz-Vergel, 2014) söz konusudur. Bu araştırmada da duygusal emeğin işle bütünleşme ile ilişkisi ortaya konmuş ve duygusal emek davranışlarının işle bütünleşmeyi olumlu etkilediği sonucuna varılmıştır.

Öğretmenlerin mesleğe olan inancı, bağlılı̆̆ ve beraberindeki motivasyonu, mesleğin etkililiği ve işlevselliği bağlamında önem taşımaktadır. Buradan hareketle sonraki çalışmalarda öğretmenlerin işle 
bütünleşmesine etki eden faktörler nitel araştırma teknikleri veya nitel ve nicel araştırma teknikleri birlikte kullanılarak derinlemesine incelenebilir. İşle bütünleşme davranışının özellikle öz yeterlik algısı, örgüt iklimi, yönetici ve meslektaş davranışı gibi faktörlerle olan ilişkisi incelenerek öğretmenlerin mesleğini özümseyerek yapmaları yönünde destekleyici faktörler ortaya konabilir. Ayrıca işle bütünleşmeye etki edebilecek psikolojik temelli bireysel faktörler ve örgütsel davranış faktörleri araştırılıp bu değişkenlerle ilişkileri de incelenebilir. Sözü edilen araştırma önerilerinin yalnızca lise öğretmenleriyle sınırlı tutulmayıp tüm öğretim kademelerinde gerçekleştirilerek sonuçlara ilişkin bir karşılaştırma yapılmasının da literatüre önemli katkı sağlayacağ1 düşünülmektedir.

\section{KAYNAKÇA}

Akman, Y. ve İmamoğlu-Akman, G. (2017). İlköğretim okulu öğretmenlerinin iş yaşam kalitesi algısının işle bütünleşmeleri üzerindeki etkisi. Illköğretim Online, 16(4), 1491-1504. DOİ: 10.17051/ilkonline.2017.342971

Albrecht, K. (2006). Social intelligence: The New science of success. San Francisco, CA: Jossey Bass. Arı, S. (2011). Örgütsel İklimin İşle Bütünleşme Üzerine Etkisi ve Bir Uygulama. Yüksek Lisans Tezi. https://tez.yok.gov.tr sayfasından erişilmiştir.

Ashforth, B. E. ve Humphrey, R. H. (1993). Emotional labor in service roles: The influence of identity. Academy of management review, 18(1), 88-115.

Aydın, İ. (2008). İş yaşamında stress. Ankara: Pegem Akademi.

Aydın, K. ve Yayla, H. E. (2018). Muhasebe meslek mensuplarının etik tutumlarının kurumsal itibar yönetimi üzerindeki etkisi. Atlas International Referred Juornal on Social Sciences, 4(8), 67-97.

Babcock-Roberson, M. E. ve Strickland, O. J. (2010). The Relationship between charismatic leadership, work engagement, and organizational citizenship behaviors, The Journal of Psychology, 144(3), 313-326.

Bakker, A. B. ve Bal, P. M. (2010). Weekly work engagement and performance: A Study among starting teachers. Journal of Occupational and Organizational Psychology, 83, 189-206.

Bakker, A., B. ve Leiter, M., P. (2010). Work Engagement: A Handbook of Essential Theory and Research, New York: Psyc-hology Press.

Bakker, A. B. ve Oerlemans, W. (2011). Subjective well-being in organizations. K. Cameron \& G. Spreitzer (Eds.), Handbook of positive organizational scholarship içinde (ss. 178-189). New York, NY: Oxford University.

Bakker, A. B., Demerouti, E. ve Sanz-Vergel, A. I. (2014). Burnout and work engagement: The JD$\mathrm{R}$ approach. Annual Review of Organizational Psychology and Organizational Behaviour, 1, 389411.

Basım, H. N. ve Begenirbaş, M. (2012). Çalışma yaşamında duygusal emek: Bir ölçek uyarlama çalışması. Yönetim ve Ekonomi, 19(1), 77-90.

Basikin, B. (2007). Vigor, dedication and absorption: Work engagement among secondary school english teachers in Indonesia. AARE Annual Conference'da sunulmuş bildiri Fremantle, Australia.

Bermejo, L., Hernández-Franco, V. ve Prieto-Ursúa, M. (2013). Teacher well-being: Personal and job resources and demands. Procedia-Social and Behavioral Sciences 84, 1321-1325.

Brotheridge, C. M. ve Grandey, A. A. (2002). Emotional labor and burnout: Comparing two perspectives of "people work". Journal of Vocational Behaviour, 60, 17-39. 
Brown, R. B. ve Brooks, I. (2002). Emotion at work: Identifying the emotional climate of night nursing. Journal of Management In Medicine, 16(5), 327-344.

Collins, K. K. (2009). Examining A Strengths-Based Approach To Employee Engagement And The Mediating Effects of Strengths Self-Efficacy. Doctoral Dissertation. www.proquest.com/libraries/academic/dissertations-theses sayfasından erişilmiştir

Chughtai, A. ve Buckley, F. (2009). Linking trust in the principal to school outcomes: The mediating role of organizational identification and work engagement. International Journal of Educational Management, 23(7), 574-589.

Çelik: N. (2019). Öğretmenlerin İşle Bütünleşme Düzeyleri ile Değişime Dirençleri Arasındaki İlişskinin İncelenmesi. Yüksek Lisans http://earsiv.kastamonu.edu.tr:8080/xmlui/bitstream/handle/123456789/323/Semiyya\%20Nur\%20\% c3\%87EL\%c4\%b0K.pdf?sequence=1\&isAllowed=y sayfasından erişilmiştir.

Demirbaş, H. T. (2008). İş Özellikleri Algısının İş Bütünleşmesi Üzerindeki Etkisi (İDO A.Ş.’’de Bir Uygulama). Yüksek Lisans Tezi. https://tez.yok.gov.tr sayfasından erişilmiştir.

Diefendorff, J. M., Croyle, M. H. ve Grosserand, R. H. (2005), The dimensionality and antecedents of emotinal labor strategies, Journal of Vocational Behavior, 66, 339-357.

Diefendorff, J. M. ve Gosserand, R. H. (2003). Understanding the emotional labor process: A control theory perspective. Journal of Organizational Behavior, 24, 945-959.

Emeksiz, E. (2015). İş Doyumunun Yordayıcısı Olarak Çok Boyutlu Örgütsel Kimliklenme: İşle Bütünleşmenin Aracılık Rolü. Yayımlanmamış Yüksek Lisans Tezi, Bahçeşehir Üniversitesi, Eğitim Bilimleri Enstitüsü, İstanbul.

Goffman, E. (1959). The presentation of self in everday life. New York: Doubleday Anchor,

Grandey, A. A. (2000). Emotion regulation in the workplace: A new way to conceptualize emotionallabor. Journal of Occupational HealthPsychology, 5(1), 95-110. DOİ: 10.1037//10768998.5.1.95

Grandey, A. A. (2003). When "the show must go on": Surface acting and deep acting as determinants of emotional exhaustion and peer-rated service delivery. Academy of Management Journal, 46(1), 86-96.

Guglielmi, D., Bruni, I., Simbula. S, Fraccaroli, F. ve Depolo, M. (2014). What drives teacher engagement: A study of different age cohorts. European Journal of Psychology of Education, 31, 323-340.

Gündüz, B., Çapri, B. ve Gökçakan, Z. (2013). Mesleki tükenmişlik, işle bütünleşme ve iş doyumu arasındaki ilişkilerin incelenmesi. Ĕgitim Bilimleri Araştırmaları Dergisi-Journal of Educational Sciences Research, 3(1), 29-49. DOI: 10.12973/jesr.2013.312a.

Gürel, E. ve Bozkurt, Ö. (2016). Duyguların yönetilmesinin, iş tatmini ve duygusal tükenmişlik düzeyi üzerine etkileri. Mehmet Akif Ersoy Üniversitesi Sosyal Bilimler Enstitüsü Dergisi, 8(14), 133147.

Hair, J. F., Black, W. C., Babin, B. J., Anderson, R. E. ve Tatham, R. L. (2013). Multivariate data analysis: Pearson Education Limited.

Hakanen, J. J., Bakker, A. B. ve Schaufeli, W. B. (2006). Burnout and engagement among teachers. Journal of School Psychology, 43, 495-513.

Halbesleben, J. R. B. (2010). A meta-analysis of work engagement: Relationships with burnout, demands, resources and consequences. In A. B. Bakker \& M. P. Leiter (Eds.), Work engagement: A handbook of essential theory and research (pp. 118-131). New York, NY: Psychology Press. 
Hallberg, U. ve Schaufeli, W. B. (2006). "Same same" but different: Can work engagement be discriminated from job involvement and organizational commitment? European Journal of Psychology, 11, 119-127.

Han, J., Yin, H. ve Wang, W. (2016). The effect of tertiary teachers' goal orientations for teaching on their commitment: the mediating role of teacher engagement. Educational Psychology, 36(3), 526547.

Hochschild, A. R (1979). Emotion work, feeling rules, and social structure. The American Journal of Sociology, 85(3), 551-575.

Hochschild, A. R. (2003). The managed heart: Commercialization of human feeling. Berkeley: University of California Press.

Høigaard, R., Giske, R. ve Sundsli, K. (2012). Newly qualified teachers' work engagement and teacher efficacy influences on job satisfaction, burnout, and the intention to quit. European Journal of Teacher Education, 35(3), 347-357.

İnanır, B. (2020). Öğretmenlerin İşle Bütünleşme Düzeyleri ile Okul İklimi ve Öğretmen Liderliği Arasındaki İlişkinin İncelenmesi. Yüksek Lisans Tezi. http://earsiv.kastamonu.edu.tr:8080/xmlui/bitstream/handle/20.500.12597/1363/Batuhan\%20I\%CC $\% 87$ nan\%C4\%B1r\%20Tez.pdf?sequence=1\&isAllowed=y sayfasından erişilmiştir.

Kahn, W. A. (1990). Psychological conditions of personal engagement and disengagement at work. The Academy of Management Journal, 33(4), 692-724.

Karakaş, A., Tösten, R., Kansu, V. ve Aydın, A. S. (2016). Öğretmenlerin duygusal emek davranışlarının iş doyumlarına etkisi. Elektronik Sosyal Bilimler Dergisi, 15(56), 177-188.

Karasar, N. (2010). Bilimsel araştırma yöntemi. Ankara: Nobel.

Katz, D. ve Kahn, R. L. (1977). Örgütlerin toplumsal psikolojisi. (H. Can \& Y. Bayar, Çev.). Ankara: TODAİE.

Kavgacı, H. (2014). İlköğretim Kurumu Öğretmenlerinin İşle Bütünleşme Düzeylerinin Bireysel ve Örgütsel Değişkenlerle İlişkisi. Doktora Tezi. Gazi Üniversitesi, Eğitim Bilimleri Üniversitesi, Ankara.

Kirkpatrick, C. L. (2009). Engaging Second-Stage Teachers in Their Work: The Role of Professional Culture in Schools Unpublished Doctoral Dissertation. Harvard University, USA.

Konermann, J. (2011). Teachers' Work Engagement: A Deeper Understanding of The Role of Job and Personal Resources in Relationship to Work Engagement, Its Antecedents, And Its Outcomes Doctoral Dissertation. Universiteit Twente, Belgium. https://ris.utwente.nl/ws/portalfiles/portal/6062312/thesis_J_Konermann.pdf sayfasindan erişilmiştir.

Kong, Y. (2009). A study on the relationships between job engagement of middle school teachers and its relative variables. Asian Social Science, 5(1), 105-108.

Lehtinen, T. A. (2013). Quality of Working Life and Engagement in an Evolving Hospitality Subsector: The Case of Hostels. Master's Thesis, Instituto Universitario de Lisboa, ISCTE Business School, Lisboa.

Lin-Chu, K. H. (2002). The Effects of Emotional Labor on Employee Work Outcomes. Unpublished. Doctoral Dissertation. Virginia Polytechnic Institute and State University, USA.

Macey, W. H. ve Schneider, B. (2008). The meaning of employee engagement. Industrial and Organizational Psychology, 1, 3-30.

Maslach, C. ve Leiter, M.P. (1997). The truth about burnout: How organizations cause personal stress and what to do about it. San Francisco, CA: Jossey-Bass. 
Maslach, C. ve Goldberg, J. (1998). Prevention of burnout: new perspectives. Applied \& Preventive Psychology, 7, 63-74.

Maslach, C. ve. Jackson S. E. (1981). The measurement of experienced burnout. Journal Of Occupational Behavior, 2, 99-113.

Maslach, C., Schaufeli, W. B. ve Leiter, M. P. (2001). Job burnout. Annual review of psychology, 52(1), 397-422.

Mastracci:H., Newman, M. A. ve Guy, M. E. (2006). Appraising emotional work: Determining whether emotional labor is valued in government jobs. American Review of Public Administration, $36(2), 123-138$.

Miller, K. I., Considine, J. ve Garner, J. (2007). Let me tell you about my job: Exploring the terrain of emotion in the workplace. Management Communication Quarterly, 20(3), 231-260.

Morris, J. A. ve Feldman, D. C. (1997). Managing emotions in the workplace. Journal of Managerial Issues, 9(3), 257-274.

Näring, G., Vlerickc, P. ve Van de Ven, B. (2012). Emotion work and emotional exhaustion in teachers: The job and individual perspective. Educational Studies, 38(1), 63-72.

Oral, L. ve Köse: (2011). Hekimlerin duygusal emek kullanımı ile iş doyumu ve tükenmişlik düzeyleri arasındaki ilişkiler üzerine bir araştırma. Süleyman Demirel Üniversitesi İktisadi ve İdari Bilimler Fakültesi Dergisi, 16(2), 463-492.

Öncel, L. (2007). Öğretmenlerin İşleriyle Bütünleşme Düzeylerinin Performansları ve İş Yerlerinden Ayrılma Niyetleriyle İlişkisi. Yüksek Lisans Tezi. https://tez.yok.gov.tr sayfasından erişilmiştir.

Öngöre, Ö. (2013). İşle Bütünleşme Ölçeği Türkçe Formu'nun güvenilirlik ve geçerlilik çalışması. Kastamonu Üniversitesi İktisadi ve İdari Bilimler Dergisi, 2(2), 50-60.

Pala, T. ve Sürgevil, O. (2016). Duygusal emek ölçeği: Ölçek geliştirme, güvenilirlik ve geçerlilik çalışması. Ege Akademik Bakış, 16(4), 773-787.

Rich, B. L. (2006). Job engagement: Construct validation and relationships with job satisfaction, job involvement, and intrinsic motivation. University of Florida. Pro Quest Dissertations and Theses, 197.

Rich, B. L., Lepine, J. A. ve Crawford, E. R. (2010). Job engagement: antecedents and effects on job performance. Academy of Management Journal, 53(3), 617-635.

Saks, A. M. (2006). Antecedents and consequences of employee engagement. Journal of Managerial Psychology, 21, 600-619.

Schaufeli, W. B., Salanova, M., Gonzàlez-Romà, V. ve Bakker, A. B. (2002). The measurement of burnout and engagement: A two sample confirmative analytic approach. Journal of Happiness Studies, 3(1), 71-92. doi:10.1023/A:1015630930326

Schaufeli, W. B. (2014). What is engagement? C. Truss, R. Delbridge, K. Alfes, A. Shantz, E. Soane (Ed.), Employee engagement in theory and practice içinde (ss. 15-35). Routledge.

Schmitt, A. (2012). Refinement of Theoretical Frameworks on Antecedents of Work Engagement and of Affective Events Theory: A Dynamic Approach. Doctoral Dissertation. http://opus.unilueneburg.de sayfasından erişilmiştir.

Sezen, G. (2014). Öğretmenlerin İşle Bütünleşme ve İş Yaşamında Yalnızlık Düzeyleri Arasındaki İlişkinin İncelenmesi. Yüksek Lisans Tezi. https://tez.yok.gov.tr sayfasından erişilmiştir.

Simbula. S., Guglielmi, D. ve Schaufeli, W. B. (2011). A three-wave study of job resources, selfefficacy, and work engagement among Italian school teachers. European Journal of Work and Organizational Psychology, 20(3), 285-304. 


\section{Al-Farabi International Journal on Social Sciences}

Topateş, H. ve Kalfa, A. (2009). Yeni çalışma ilişkileri bağlamında örgütsel yurttaşlık ve duygusal emek. Uluslararası Sosyal Haklar Sempozyumu bildirileri, 423-431.

Yıldırım, A. ve Şimşek, H. (2006). Sosyal bilimlerde nitel araştırma yöntemleri (6. Baskl). Ankara: Seçkin.

Yürür, Ş. ve Ünlü, O. (2011). Duygusal emek, duygusal tükenme ve işten ayrılma niyeti ilişkisi. IşsGüç Endüstri İlişkileri ve İnsan Kaynakları Dergisi, 13(2), 81-104. 